pISSN: 2548-9879

elSSN: 2599-2139

\title{
FAKTOR-FAKTOR YANG MEMPENGARUHI PENERIMAAN MAHASISWA TERHADAP E-LEARNING EXELSA MOODLE DENGAN MENGGUNAKAN GETAMEL
}

\author{
Nicolas Bayu Kristiawan* \\ Pendidikan Akuntansi, Universitas Sanata Dharma
}

\section{Edcomtech}

Jurnal Kajian Teknologi

Pendidikan

Volume 6, No 2, Oktober 2021

275-287

DOI: 10.17977/um039v6i12021p275

Submitted 25-02-2021

Accepted 10-05-2021

\section{Corresponding Author*}

Nicolas Bayu Kristiawan

Universitas Sanata Dharma

Mrican, Caturtunggal, Depok,

Sleman, Yogyakarta 55281

Email: nicolasbayu@usd.ac.id

OPEN ACCESS

\section{Abstrak}

Tujuan penelitian ini adalah menguji penerimaan mahasiswa terhadap elearning Exelsa Moodle dengan menggunakan General Extended Technology Acceptance Model for e-learning (GETAMEL) yang dikembangkan oleh Fazil \& Rupert. Model GETAMEL digunakan dengan tujuan untuk mengetahui secara spesifik faktor-faktor yang berpengaruh terhadap penerimaan mahasiswa terhadap e-learning Exelsa Moodle. Berdasarkan GETAMEL, terdapat lima faktor eksternal yang mempengaruhi penerimaan mahasiswa terhadap e-learning, yaitu: pengalaman dalam menggunakan komputer dan teknologi informasi, norma subjektif, persepsi kenyamanan dalam menggunakan komputer dan teknologi informasi, kecemasan dalam menggunakan komputer dan teknologi informasi, dan self efficacy. Metode penelitian survey digunakan untuk mengukur variabel dalam GETAMEL. Hasil dalam penelitian ini menunjukan bahwa tidak semua variabel eksternal dalam GETAMEL berpengaruh terhadap persepsi kemudahan dan persepsi kebermanfaatan dalam TAM. Hanya 2 variabel yang berpengaruh yaitu : variabel kenyamanan dalam menggunakan e-learning, hanya berpengaruh terhadap persepsi kemudahan dalam menggunakan e-learning Exelsa Moodle sedangkan variabel self efficacy berpengaruh terhadap persepsi kemudahan dalam menggunakan e-learning Exelsa Moodle dan persepsi kebermanfaatan dalam menggunakan e-learning Exelsa Moodle. Selanjutnya, semua variabel dalam TAM berpengaruh secara signifikan.

Kata Kunci: TAM, GETAMEL, e-learning

\section{Abstract}

The purpose of this study was to test student acceptance of Exelsa Moodle's e-learning using the General Extended Technology Acceptance Model for elearning (GETAMEL) developed by Fazil \& Rupert. The GETAMEL model is used with the aim of knowing specifically the factors that influence student acceptance of Exelsa Moodle e-learning. Based on GETAMEL, there are five external factors that influence student acceptance of e-learning, namely: experience in using computers and information technology, subjective norms, perceived comfort in using computers and information technology, anxiety in using computers and information technology, and self-efficacy. Survey research method is used to measure variables in GETAMEL. The results in this study indicate that not all external variables in GETAMEL affect the perception of convenience and the perception of usefulness in TAM. Only 2 variables have an effect, namely: the convenience variable in using e-learning, only affects the perception of ease in using Exelsa Moodle e-learning while the selfefficacy variable affects the perception of ease in using Exelsa Moodle elearning and the perceived usefulness in using e-learning Excel Moodle. Furthermore, all variables in TAM have a significant effect.

Keywords: TAM, GETAMEL, e-learning 


\section{LATAR BELAKANG}

Perkembangan Internet dan teknologi informasi mempengaruhi banyak aspek, salah satunya adalah aspek pendidikan. Hal ini nampak dari e-learning yang semakin banyak digunakan dan dikembangkan. Meskipun demikian, tidak semua e-learning yang dikembangkan dapat diterima oleh pengguna, yaitu, siswa. Penerimaan terhadap e-learning mengindikasikan keberhasilan penggu-naan e-learning dalam proses belajar mengajar. Oleh sebab itu, penting bagi pendidik maupun orang yang mengembangkan sistem e-learning untuk mengetahui faktor-faktor yang mempe-ngaruhi penerimaan terhadap suatu e-learning. Dengan mengetahui faktorfaktor tersebut, guru, dosen, maupun pemimpin institusi pendidikan dapat merancang suatu sistem pembelajaran $e$ learning yang dapat diterima sesuai dengan konteks pembelajaran di kelas, di suatu institusi pendidikan, maupun pendidikan di suatu daerah.

Tingkat penerimaan terhadap suatu sistem atau teknologi informasi dapat diukur melalui model TAM (Technology of Acceptance Model) yang dikembangkan oleh Davis (1985). Variabel dalam TAM antara lain: perceived ease of use (persepsi kemudahan), perceived usefulness (persepsi kebermanfaatan), attitude towards usage (sikap dalam penggunaan teknologi), intention to use (niat dalam menggunakan teknologi), dan actual use. Faktor-faktor eksternal yang mempeng-aruhi variabel tersebut sangat kontekstual sesuai dengan kondisi individu dan lingkungan masingmasing. Dalam penelitian ini model yang digunakan untuk mengukur tingkat penerimaan mahasiswa terhadap e-learning Exelsa Moodle adalah General Extended Technology Acceptance Model For e-learning (GETAMEL) yang dikembangkan oleh Fazil \& Rupert (2016). GETAMEL merupakan pengembangan dari Technology of Acceptance Model (TAM). Berbeda dengan TAM, GETAMEL menguji faktor eksternal yang mempengaruhi penerimaan individu terhadap teknologi informasi, khususnya $e$ learning. Faktor-faktor tersebut antara lain pengalaman dalam menggunakan komputer dan teknologi informasi, norma subyektif, persepsi kenyamanan dalam menggunakan komputer dan teknologi informasi, kecemasan dalam menggunakan komputer dan teknologi informasi, dan self efficacy. Penelitian ini bertujuan menguji faktorfaktor yang mempengaruhi tingkat penerimaan mahasiswa Program Studi Pendidikan Akuntansi Universitas Sanata Dharma, terhadap penggunaan e-learning Exelsa Moodle dengan GETAMEL. Hasil dalam penelitian ini menunjukan bahwa variabel pengalaman, norma subyektif, dan kecemasan tidak berpengaruh secara signifikan terhadap persepsi kemudahan dan persepsi kebermanfaatan dalam menggunakan e-learning Exelsa Moodle. Hal ini disebabkan karena mahasiswa merupakan digital natives, yang terlahir dan tumbuh dengan komputer dan teknologi informasi. Variabel lain yaitu kenyamanan berpengaruh signifikan terhadap persepsi kemudahan dan self efficacy berpengaruh terhadap persepsi kemudahan dan persepsi kebermanfaatan menggunakan e-learning. Hal ini menunjukan bahwa mahasiswa merasa percaya diri dan nyaman ketika menggunakan Exelsa Moodle.

\section{E-learning}

E-learning didefinisikan sebagai suatu cara, metode atau alat yang memanfaatkan teknologi jaringan komputer seperti internet, intranet, dan ekstranet yang digunakan untuk mengirimkan materi pengajaran kepada siswa dan dapat diintegrasikan dengan berbagai macam materi pengajaran baik itu video, audio, maupun teks melalui e-mail, live chat sessions, online discussions, forum diskusi, kuis dan penugasan (Y. M. Cheng, 2011; Engelbrecht, 2005; Lee et al., 2011; Welsh et al., 2003). Ada beberapa manfaat penggunaan e-learning di pendidikan, antara lain fleksibilitas dalam pengajaran, biaya 
yang rendah, dan persepsi kenyamanan dalam mengirimkan maupun mengumpulkan informasi. E-learning memungkinan guru untuk memberikan materi pembelajaran melalui audio, video, animasi, gambar dan teks maupun menyediakan ruang belajar dan waktu yang fleksibel, sehingga siswa dapat mengakses materi kapan saja dan dimana saja (Fazil \& Rupert, 2016).

Technology Acceptance Model \& e-learning Dalam dunia pendidikan, TAM digunakan untuk menguji beberapa factor yang berpengaruh terhadap penerimaan siswa terhadap e-learning. Penelitian terdahulu mengenai e-learning menunjukan bahwa TAM merupakan pengukur yang valid dan robust, sangat mampu menjelaskan faktor yang mempengaruhi penggunaan $e$ learning, dan paling banyak digunakan dalam penelitian tentang e-learning (King \& $\mathrm{He}$, 2006; Šumak et al., 2011). Faktor-faktor tersebut antara lain: computer self efficacy, perceived flexibility, locus of control, perceived convenience, subjective norm, experience, computer anxiety, dll. Fazil \& Rupert (2016) merangkum berbagai faktor yang mempengaruhi penerimaan siswa dalam e-learning melalui TAM dan mengembangkan model baru yang disebut dengan General Extended Technology Acceptance Model for e-learning (GETAMEL).

\section{Faktor-Faktor yang mempengaruhi}

Penerimaan Mahasiswa dalam
menggunakan e-learning Exelsa Moodle dengan menggunakan General Extendend Technology Acceptance Model (GETAMEL)

Beberapa faktor eksternal yang digunakan dalam model GETAMEL yang mempengaruhi penerimaan individu dalam penggunaan teknologi adalah: pengalaman dalam menggunakan komputer dan teknologi informasi, norma subjektif individu, persepsi kenyamanan dalam menggunakan komputer dan teknologi informasi, kecemasan dalam menggunakan komputer dan teknologi informasi dan teknologi informasi, dan self efficacy. Penelitian ini menguji pengaruh beberapa faktor tersebut terhadap penerimaan mahasiswa dalam penggunaan e-learning Exelsa Moodle.

Pengaruh Pengalaman terhadap Persepsi Kemudahan dan Persepsi Kebermanfaatan Mahasiswa dalam menggunakan e-learning Exelsa Moodle

Pengalaman dalam menggunakan komputer dan teknologi informasi didefinisikan sebagai tingkat kemampuan dan tipe kemampuan individu dalam hal penguasaan komputer selama periode waktu tertentu. Individu yang memiliki pengalaman dalam penggunaan komputer dan teknologi informasi (sebagai contoh: terbiasa dalam menggunakan komputer, internet, dan e-mail) cenderung akan memiliki persepsi yang lebih mudah dalam menggunakan e-learning dan merasakan manfaat yang lebih banyak dari sistem $e$ learning (Lee et al., 2013; Purnomo \& Lee, 2012). Kerka (1999) berargumen bahwa keberhasilan siswa yang belajar dengan memanfaatkan e-learning dipengaruhi oleh kemampuannya dalam mengoperasikan komputer dan internet. Semakin banyak pengalaman individu dalam menggunakan teknologi, maka persepsi individu terhadap penggunaan teknologi akan menjadi semakin mudah dan bermanfaat bagi diri individu tersebut. Penelitian-penelitian yang menggunakan model TAM menemukan bahwa pengalaman dalam menggunakan komputer dan teknologi informasi mempengaruhi persepsi individu mengenai kemudahan dan kebermanfaatan penggunaan e-learning (Fazil \& Rupert, 2016; Lee et al., 2013; Purnomo \& Lee, 2012). Berdasarkan pada hal tersebut, maka hipotesis dalam penelitian ini adalah:

H1: Pengalaman mahasiswa dalam menggunakan komputer dan teknologi informasi berpengaruh positif terhadap persepsi kemudahan dalam menggunakan $e-$ learning Exelsa Moodle. 
H2: Pengalaman mahasiswa dalam menggunakan komputer dan teknologi informasi berpengaruh positif terhadap persepsi kebermanfaatan dalam menggunakan $e$ - learning Exelsa Moodle.

\section{Pengaruh Norma Subjektif terhadap Persepsi Kemudahan dan Persepsi Kebermanfaatan Mahasiswa dalam menggunakan e-learning Exelsa Moodle}

Norma subjektif adalah persepsi individu mengenai pandangan orang lain terhadap dirinya mengenai apa yang boleh ataupun tidak boleh dilakukan oleh seseorang (Fishbein \& Ajzen, 1975). Dalam Theory of Reasoned Action (TRA), norma subjektif digunakan sebagai determinan langsung yang mempengaruhi behavioral intention. Namun, dalam dunia pendidikan, khususnya e-learning, norma subjektif tidak secara langsung mempengaruhi pengambilan keputusan, melainkan lebih pada bagaimana sosok dari guru, opini dari teman sebaya, dan institusi pendidikan mempengaruhi kecenderungan siswa dalam menggunakan e-learning (Fazil \& Rupert, 2016). Apabila seseorang (siswa/mahasiswa) mempersepsikan bahwa orang yang penting baginya (misalnya: guru, dosen, teman sebaya, peraturan sekolah) menyarankan dia untuk menggunakan sistem e-learning, maka orang tersebut (siswa/mahasiswa) akan menginkorporasi belief tersebut ke dalam belief nya sendiri, sehingga dia akan mempersepsikan bahwa itu penting dan bermanfaat (Cheng, 2011). Beberapa penelitian menunjukan bahwa norma subjektif berpengaruh terhadap persepsi kemudahan dan persepsi kebermanfaatan. Berdasarkan pada argumen, teori-teori, maupun hasil penelitian yang telah dibahas, maka hipotesis berikutnya yang diajukan di dalam penelitian ini adalah:

H3: Norma subjektif berpengaruh positif terhadap persepsi kemudahan dalam menggunakan $e$ - learning Exelsa Moodle.
H4: Norma subjektif berpengaruh positif terhadap persepsi kebermanfaatan dalam menggunakan e- learning Exelsa Moodle.

Pengaruh Persepsi Kenyamanan dalam Menggunakan e-learning Exelsa Moodle terhadap Persepsi Kemudahan dan Persepsi Kebermanfaatan Mahasiswa dalam menggunakan e-learning Exelsa Moodle Konsep kenyamanan (enjoyment) dalam konteks penggunaan sistem, didefinisikan sebagai tingkat persepsi kenyamanan dalam menggunakan suatu sistem berdasarkan pada persepsi masingmasing individu, tanpa mempertimbangkan hasil yang dicapai dalam penggunaan sistem tersebut (Y. Park et al., 2012). Park et al., (2012) menyatakan bahwa enjoyment (kenyamanan) mengurangi beban individu dalam penggunaan suatu sistem informasi. Enjoyment (kenyamanan) akan meningkatkan suatu persepsi positif individu terhadap sistem tersebut. Hal tersebut terjadi karena kenyamanan individu terhadap suatu sistem cenderung akan menurunkan tingkat kesulitan dalam penggunaan sistem. Hal ini akan meningkatkan keinginan untuk menggunakan sistem tersebut. Dalam penerapan di dunia pendidikan, persepsi kenyamanan terhadap penggunaan sistem ataupun teknologi dalam e-learning menjadi faktor yang penting. Hal ini disebabkan karena motivasi belajar berhubungan dengan kenyamanan siswa dalam belajar. Siswa yang merasa enjoy (nyaman) dengan sistem (e-learning) akan mempersepsikan bahwa sistem (e-learning) tersebut mudah digunakan dan bermanfaat bagi proses belajar siswa tersebut. Berdasarkan pada argumen, teori-teori maupun hasil penelitian yang telah dibahas, maka hipotesis berikutnya yang diajukan dalam penelitian ini adalah:

H5: Persepsi kenyamanan dalam menggunakan e-learning Exelsa Moodle berpengaruh positif terhadap persepsi kemudahan dalam 
menggunakan $e$ - learning Exelsa Moodle.

H6: Persepsi kenyamanan dalam menggunakan e-learning Exelsa Moodle berpengaruh positif terhadap persepsi kebermanfaatan dalam menggunakan $e$ - learning Exelsa Moodle.

Pengaruh Kecemasan dalam Menggunakan Komputer dan Teknologi Informasi terhadap Persepsi Kemudahan dan Persepsi Kebermanfaatan Mahasiswa dalam menggunakan e-learning Exelsa Moodle

Kecemasan dalam menggunakan komputer dan teknologi informasi (Computer Anxiety) dapat didefinisikan sebagai ketakutan yang muncul ketika individu dihadapkan pada kemungkinan penggunaan sistem informasi (Igbaria \& Parasuraman, 1989). Park et al. (2012) menyatakan bahwa individu yang memiliki tingkat kecemasan rendah cenderung lebih mudah berinteraksi dengan teknologi dibandingkan dengan individu yang memiliki tingkat kecemasan tinggi. Hal ini disebabkan karena individu tersebut tidak memiliki pengalaman dan kepercayaan diri dalam menggunakan teknologi informasi. Hal ini akan berpengaruh terhadap persepsi individu dalam mengadopsi teknologi tersebut. Selain itu, individu yang cemas dalam menggunakan komputer cenderung enggan untuk mengadopsi penggunaan $e$ learning . Beberapa penelitian menunjukan bahwa kecemasan dalam menggunakan komputer dan teknologi informasi berpengaruh negatif terhadap persepsi kemudahan (Agudo-Peregrina et al., 2014; Chen \& Tseng, 2012; Fazil \& Rupert, 2016; Y. Park et al., 2012) dan persepsi kebermanfaatan (Y. Park et al., 2012). Berdasarkan pada argumen, beberapa teori maupun hasil penelitian yang sudah dibahas, maka hipotesis yang diajukan di dalam penelitian ini adalah:

H7: Kecemasan dalam menggunakan komputer dan teknologi informasi berpengaruh negatif terhadap persepsi kemudahan dalam menggunakan $e$ learning Exelsa Moodle.

H8: Kecemasan dalam menggunakan komputer dan teknologi informasi berpengaruh negatif terhadap persepsi kebermanfaatan dalam menggunakan e- learning Exelsa Moodle.

Pengaruh Self Efficacy terhadap Persepsi Kemudahan dan Persepsi Kebermanfaatan Mahasiswa dalam menggunakan e-learning Exelsa Moodle

Self Efficacy dapat diartikan sebagai kepercayaan seorang individu pada kemampuan dirinya untuk dapat melaksanakan tugas dengan berhasil (Abbad et al., 2009; Bandura, 1977). Individu yang yakin bahwa ia mampu melaksanakan tugas dengan berhasil akan lebih percaya diri dalam melaksanakan tugas tersebut, termasuk kepercayaan diri dalam mengatasi kesulitan penggunaan komputer (Abdullah et al., 2017). Beberapa penelitian menemukan bahwa persepsi self efficacy mempengaruhi keputusan mengenai tindakan -tindakan apa saja yang akan diambil, konsistensi dalam melakukan suatu tindakan, dan tindakan nyata yang dilakukan (Brown \& Inouye, 1978; Wood \& Bandura, 1989). Dalam e-learning, self efficacy didefinisikan sebagai kepercayaan diri siswa pada kemampuannya dalam menggunakan learning management system (LMS) (elearning ) (Abbad et al., 2009). Menurut Abbad et al. (2009) siswa yang memiliki keyakinan yang kuat terhadap kemampuannya dalam menggunakan LMS akan mempunyai persepsi bahwa penggunaan LMS mudah dan bermanfaat. Beberapa hasil penelitian sebelumnya menemukan bahwa self efficacy memiliki pengaruh positif pada persepsi kemudahan dan persepsi kebermanfaatan penggunaan e-learning (Chen \& Tseng, 2012; Fazil \& Rupert, 2016). Berdasarkan argumen, teori dan hasil penelitian yang telah dibahas, maka hipotesis dalam penelitian ini adalah:

H9: Self efficacy berpengaruh positif terhadap persepsi kemudahan dalam 
menggunakan $e^{-}$learning Exelsa Moodle.

H10: Self efficacy berpengaruh positif terhadap persepsi kebermanfaatan dalam menggunakan e- learning Exelsa Moodle.

Pengembangan hipotesis selanjutnya didasarkan pada Theory of Acceptance Model yang dibuat dan dikembangkan oleh (Davis, 1989). TAM menjelaskan hubungan variabel penerimaan dalam teknologi yaitu antara perceived usefulness (persepsi kebermanfaatan penggunaan teknologi), perceived ease of use (persepsi kemudahan penggunaan teknologi), attitude towards usage (sikap dalam menggunakan teknologi), intention to use (niat menggunakan teknologi), dan actual use. Beberapa variabel tersebut saling mempengaruhi dan menjelaskan penerimaan individu terhadap suatu teknologi. Dalam konteks penelitian ini, yaitu penerimaan teknologi mahasiswa terhadap e-learning exelsa moodle, pengaruh variabel-variabel tersebut dijelaskan dalam pengembangan hipotesis berikut ini.

Pengaruh Persepsi Kemudahan terhadap Persepsi Kebermanfaatan Penggunaan elearning Exelsa Moodle

Persepsi kemudahan adalah tingkatan seorang individu menganggap bahwa menggunakan suatu sistem/teknologi tidak memerlukan banyak usaha (free of effort), sedangkan persepsi kebermanfaatan adalah tingkatan seorang individu menganggap bahwa penggunaan teknologi dapat meningkatkan kinerjanya (Davis, 1989). Berdasarkan pada TAM, individu yang telah mempersepsikan bahwa penggunaan teknologi adalah mudah akan menganggap bahwa penggunaan teknologi tersebut bermanfaat (Davis, 1989). Dalam konteks $e-$ learning, siswa yang menganggap suatu $e$ learning dan LMS dapat digunakan dengan mudah cenderung menganggap e-learning dan LMS tersebut bermanfaat. Penelitian sebelumnya menunjukan bahwa persepsi kemudahan dalam penggunaan e-learning berpengaruh positif terhadap persepsi kebermanfaatan dalam penggunaan $e$ learning (Mohammadi, 2015; S. Y. Park, 2009; Shroff et al., 2011)

H11: Persepsi kemudahan dalam menggunakan E-learning Exelsa Moodle berpengaruh positif terhadap persepsi kebermanfaatan dalam menggunakan $e$ learning Exelsa Moodle.

Pengaruh Persepsi Kemudahan dan Kebermanfaatan Penggunaan e-learning Exelsa Moodle terhadap Sikap dalam Menggunakan e-learning Exelsa Moodle

Berdasarkan TAM (Davis, 1989), individu yang mempersepsikan penggunaan teknologi informasi adalah mudah cenderung akan bersikap terbuka dan menerima teknologi informasi tersebut. Begitu pula individu yang mempersepsikan penggunaan teknologi informasi bermanfaat (dapat meningkatkan kinerjanya), akan cenderung lebih mudah menerima teknologi informasi tersebut. Hal ini dapat diterapkan di dalam e-learning. Siswa yang percaya bahwa menggunakan e-learning adalah mudah dan bermafaat serta dapat membantu siswa tersebut dalam memahami materi kuliah dan menyelesaikan tugas yang diberikan akan mempunyai sikap yang lebih menerima e-learning tersebut. Berdasarkan argument tersebut, hipotesis yang diajukan adalah:

H12: Persepsi kemudahan dalam menggunakan e-learning Exelsa Moodle berpengaruh positif terhadap sikap dalam menggunakan e- learning Exelsa Moodle.

H13: Persepsi kebermanfaatan dalam menggunakan e-learning Exelsa Moodle berpengaruh positif terhadap sikap dalam menggunakan e- learning Exelsa Moodle.

Pengaruh Sikap dalam menggunakan Elearning Exelsa Moodle terhadap Niat Untuk Menggunakan E-learning Exelsa Moodle

Dalam TAM (Davis, 1989), individu yang memiliki sikap menerima sistem atau 
teknologi informasi cenderung akan memiliki intention (niat) untuk menggunakan sistem tersebut secara berkelanjutan. Hal ini disebabkan karena individu yang memiliki sikap menerima suatu teknologi maupun sistem informasi cenderung akan mempersepsikan sistem atau teknologi informasi tersebut bermanfaat dalam meningkatkan kinerjanya. Dengan persepsi tersebut, individu akan memiliki intention (niat) untuk terus menggunakan sistem dan teknologi informasi dalam jangka panjang (karena individu tersebut merasakan manfaat dalam meningkatkan kinerjanya). Dalam e-learning model TAM ini juga dapat diaplikasikan. Siswa yang memiliki sikap menerima e-learning akan menggunakan $e$ learning tersebut secara berkelanjutan. Hal ini disebabkan karena siswa merasakan manfaat yang didapatkan ketika menggunakan e-learning Exelsa Moodle yaitu adanya peningkatan pemahaman dan penyelesaian tugas. Berdasarkan pada kajian teori dan argument maka hipotesis yang diajukan adalah

H14: Sikap dalam menggunakan E-learning

Exelsa Moodle berpengaruh positif

terhadap niat untuk menggunakan

Exelsa Moodle

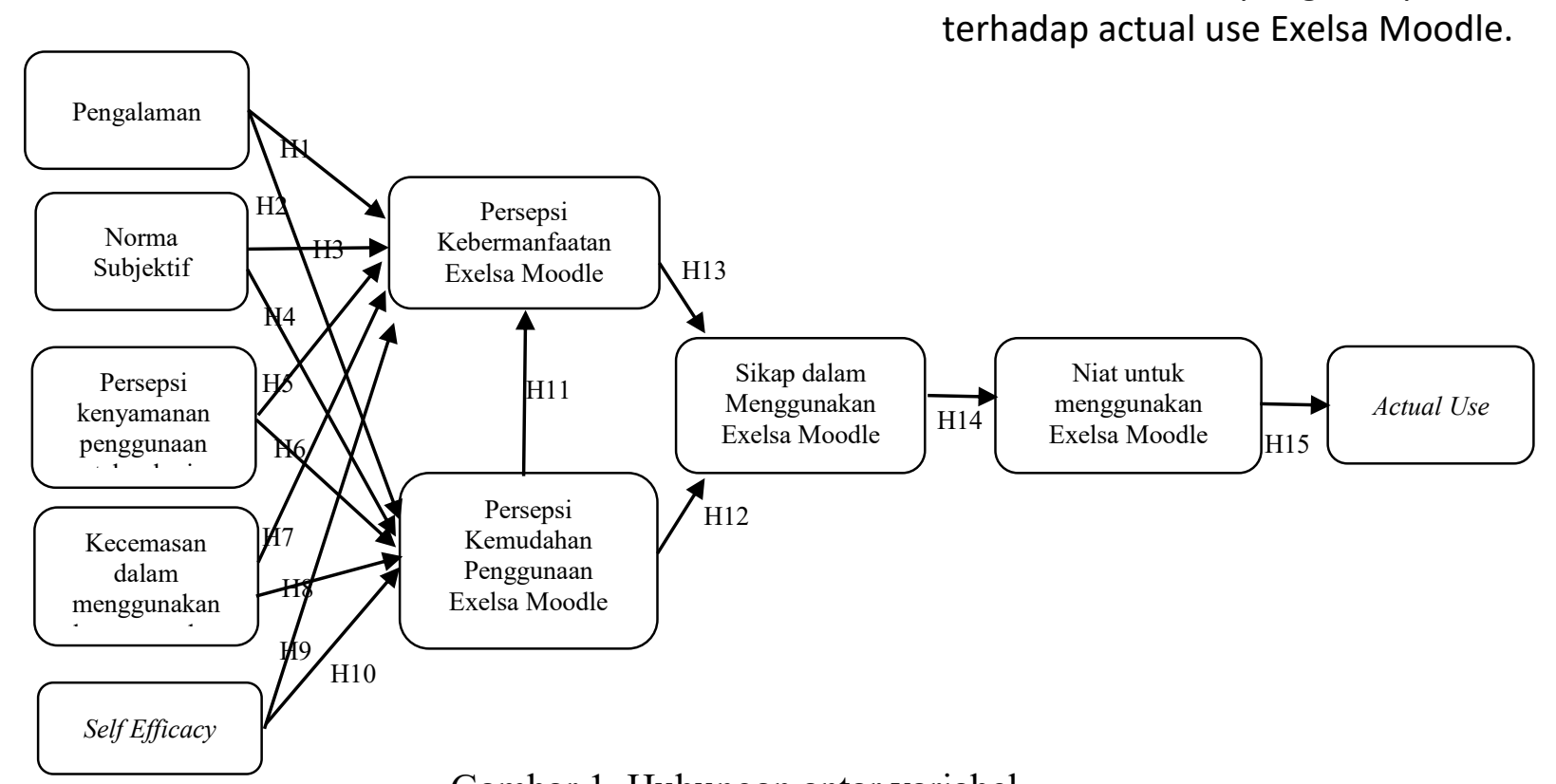

Pengaruh Niat untuk Menggunakan Elearning Exelsa Moodle terhadap Actual Use E-learning Exelsa Moodle

Dalam TAM (Davis, 1989), individu yang memiliki niat dalam menggunakan teknologi cenderung menggunakan teknologi tersebut secara aktual. Hal ini disebabkan karena intention (niat) yang dimiliki mendorong individu untuk menggunakan secara aktual sistem tersebut. Dalam penelitian sistem informasi, beberapa penelitian tidak menguji actual use sistem, karena menganggap bahwa niat dan actual use cenderung memiliki hubungan yang pasti. Meskipun demikian, penelitian ini menganggap bahwa keberhasilan suatu sistem tidak hanya terletak pada persepsi dan niat saja, tetapi juga pada penggunaan aktual suatu sistem, dalam hal ini adalah $e$ learning Exelsa Moodle. Oleh sebab itu penting bagi peneliti untuk mengukur tingkat penggunaan E-learning Exelsa Moodle selain mengukur persepsi dan niat mahasiswa dalam menggunakan Exelsa Moodle. Berdasarkan pada argumen tersebut, hipotesis berikutnya yang peneliti ajukan di dalam penelitian ini adalah $\mathrm{H} 15$ : Niat untuk menggunakan E-learning Exelsa Moodle berpengaruh positif terhadap actual use Exelsa Moodle.

Gambar 1. Hubungan antar variabel 


\section{METODE}

Penelitian ini merupakan penelitian kuantitatif dengan tujuan untuk menguji hipotesis. Pengujian hipotesis dilakukan dengan menggunakan instrumen penelitian (kuesioner). Pengembangan hipotesis didasarkan pada teori-teori yang kemudian akan diuji. Data primer digunakan dalam penelitian ini melalui instrumen kuesioner yang diedarkan kepada responden. Responden penelitian ini adalah mahasiswa Program Studi Pendidikan Akuntansi Universitas Sanata Dharma yang mengambil mata kuliah yang menggunakan e-learning Exelsa Moodle.

Unit analisis penelitian ini adalah tingkat persepsi penerimaan mahasiswa yang mengambil mata kuliah yang menggunakan e-learning Exelsa Moodle yang diukur dengan menggunakan model GETAMEL. Populasinya adalah semua mahasiswa Prodi Pendidikan Akuntansi yang mengambil mata kuliah yang menggunakan e-learning Exelsa Moodle yang berjumlah 320 mahasiswa. Jumlah sampel mahasiswa yang digunakan adalah 95 mahasiswa. Pengukuran masing-masing variabel penelitian menggunakan instrumen yang diadaptasi dari model TAM dan GETAMEL. Skala likert digunakan dalam pengembangan instrumen penelitian yang terdiri dari 5 poin yaitu, 1 = sangat tidak setuju, 2 = tidak setuju, $3=$ Netral, $4=$ setuju, $5=$ sangat setuju. Instrumen diadaptasi dari instrumen pengukuran TAM yang dikembangkan oleh Davis (1989), Venkatesh \& Davis (2000), dan Venkatesh \& Bala (2008).

Instrumen pengukuran variabel eksternal yang digunakan dalam GETAMEL diadaptasi dari beberapa penelitian. Variabel eksternal "pengalaman dalam menggunakan komputer dan teknologi informasi" mengadaptasi instrumen yang dikembangkan oleh Lee et al., (2013) dan Abdullah et al. (2017), variabel "norma subyektif" mengadaptasi instrumen dari Yoo, Han, \& Huang (2012) dan Abdullah et al., (2017), variabel "kenyamanan dalam menggunakan Exelsa Moodle" mengadaptasi instrumen dari penelitian yang dilakukan oleh Y. Park et al. (2012) dan Abdullah et al., (2017), variabel "kecemasan dalam menggunakan komputer" mengadaptasi instrumen dari penelitian yang dilakukan oleh Venkatesh \& Bala (2008), dan variabel "self efficacy" diadaptasi dari instrumen yang dikembangkan oleh Abdullah et al. (2017).

Pengolahan data menggunakan alat uji analisis Structural Equation Modeling Partial Least Square (SEM-PLS). Program yang digunakan adalah Smart PLS V 3.2.9. Penggunaan alat uji analisis Structural Equation Modeling (SEM) dengan alasan karena alat uji ini memiliki kemampuan untuk menguji model penelitian yang kompleks secara simultan (Sholihin \& Ratmono, 2013). Pemilihan SEM - Partial Least Square (SEM-PLS) disebabkan karena beberapa kelebihan yang dimiliki oleh SEM PLS dibandingkan Covariance Based SEM (CB-SEM), meskipun terdapat beberapa keterbatasan yang dimiliki oleh SEM-PLS dibandingkan dengan CB-SEM. Menurut Sholihin \& Ratmono (2013) beberapa kelebihannya antara lain: tidak membutuhkan sampel yang terlalu banyak, tidak mensyaratkan asumsi distribusi data, dan dapat mengestimasi model yang kompleks dengan banyak jalur. Meskipun demikian, terdapat beberapa keterbatasan yang perlu dipertimbangkan sebelum menggunakan SEM-PLS, antara lain: hanya mempu mengestimasi model satu arah, bertujuan untuk penelitian yang bersifat eksploratif saja, terbatas menggunakan data kategorik untuk mengukur variabel endogen. Dengan mempertimbangkan beberapa keterbatasan yang dimiliki SEMPLS, penelitian ini masih bisa mentoleransi keterbatasan alat uji analisis SEM-PLS. Hal ini disebabkan karena model dalam penelitian ini hanya menguji satu arah, tidak menggunakan variabel endogen, dan penelitian ini bertujuan untuk eksploratif, sehingga masih cocok digunakan. Selain itu, 
penelitian ini juga mempertimbangkan sampel minimum yang digunakan dalam SEM-PLS. Menurut Sholihin \& Ratmono (2013), minimum sampel yang digunakan agar dapat_menggunakan SEM-PLS adalah sama atau sepuluh kali lebih besar dari jumlah indikator formatif terbesar yang digunakan untuk mengukur konstruk, atau sepuluh kali jumlah jalur struktural terbesar yang mengarah pada konstruk tertentu dalam model. Jumlah indikator dan jalur terbesar yang mengenai sebuah konstruk adalah 6 indikator. Berdasarkan pada ketentuan tersebut maka jumlah sampel minimal untuk penelitian ini adalah 60 sampel. Selain pendekatan tersebut, peneliti juga mempertimbangkan perhitungan sampel dengan menggunakan pendekatan Cohen (1992), Berdasarkan pada pendekatan tersebut, jika dalam model penelitian ini jumlah anak panah terbesar yang mengenai satu konstruk adalah sebanyak 6 , dengan tingkat signifikansi $5 \%$ dan $R^{2}$ minimum sebesar 0,25 maka ukuran sampel minimum adalah 75 . Total sampel yang digunakan dalam penelitian ini adalah 95, sehingga dapat disimpulkan sampel yang digunakan masih layak.

\section{HASIL}

\section{Validitas dan Reliabilitas}

Hasil Pengujian Validitas dan Reliabilitas dipaparkan di tabel 1 dan tabel 2 . Tabel 1 menunjukan pengujian validitas instrumen dengan mengujinya melalui pengujian convergent validity dan discriminant validity. Dalam penelitian ini, convergent validity diuji dengan melihat nilai outer loading pada setiap indikator dan nilai AVE (Average Variance Extracted) pada setiap konstruk/variabel. Discriminant validity diuji dengan melihat nilai Cross Loading pada setiap konstruk/variabel. Convergent validity Instrumen dikatakan memenuhi syarat apabila nilai outer loading pada setiap indikator adalah $>0,7$ untuk confirmatory research dan > 0,6 untuk exploratory research dan nilai AVE pada-
Tabel 1. Convergent Validity (Outer Loading \& AVE) dan Discriminant Validity (Cross Loading)

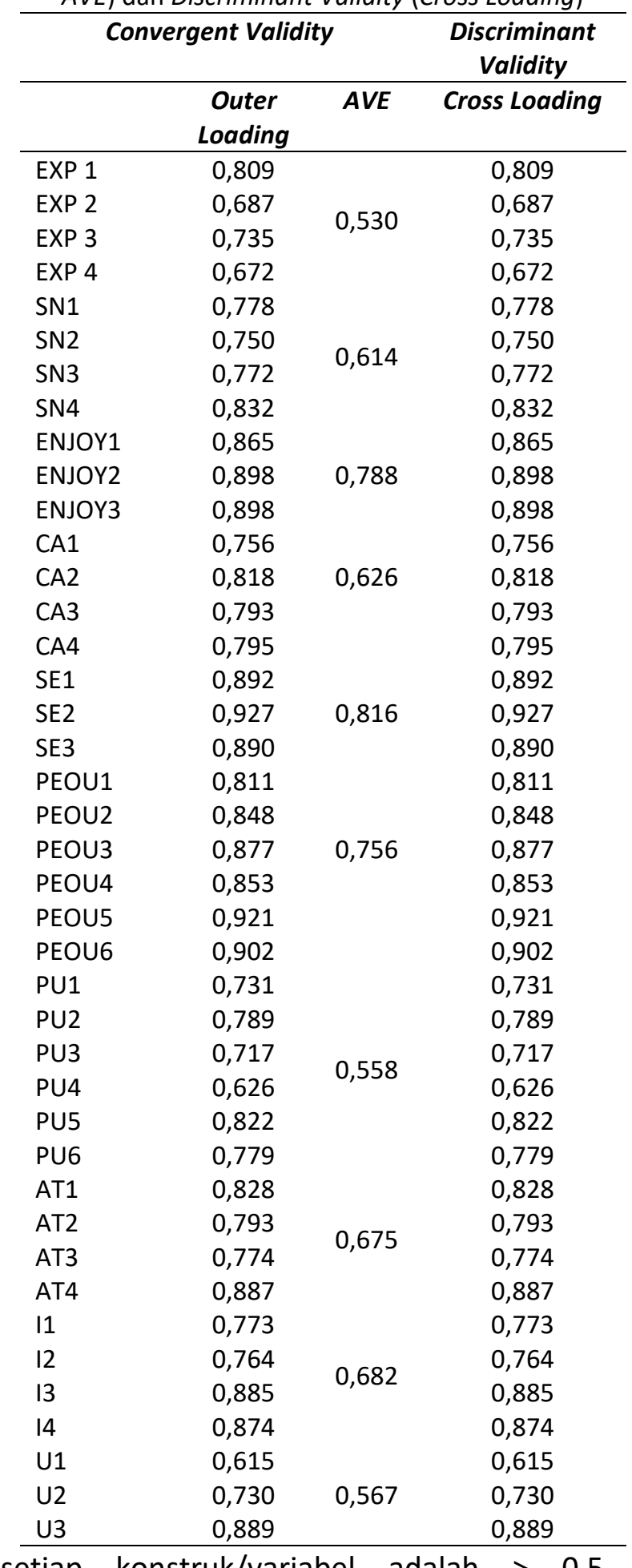

setiap konstruk/variabel adalah $>0,5$ (Ghozali \& Latan, 2014; Sholihin \& Ratmono, 2013; Wijaya, 2019). Discriminant Validity instrumen dikatakan baik apabila nilai cross loading pada setiap konstruk/ variabel adalah $>0,7$ untuk confirmatory research dan > 0,6 untuk exploratory research (Ghozali \& Latan, 2014; Sholihin \& Ratmono, 2013; Wijaya, 2019). 
Tabel 2. Croanbach's Alpha dan Composite Reliability

\begin{tabular}{lcc}
\hline Croanbach's & $\begin{array}{c}\text { Composite } \\
\text { Alpha }\end{array}$ & Reliability \\
\hline EXP & 0,706 & 0,818 \\
SN & 0,790 & 0,864 \\
ENJOY & 0,865 & 0,917 \\
CA & 0,805 & 0,870 \\
SE & 0,887 & 0,930 \\
PEOU & 0,935 & 0,949 \\
PU & 0,840 & 0,882 \\
AT & 0,839 & 0,892 \\
I & 0,844 & 0,895 \\
U & 0,602 & 0,793 \\
\hline
\end{tabular}

Berdasarkan pada tabel 1 nilai outer loading untuk setiap indikator menunjukan nilai > 0,6 , sedangkan nilai AVE untuk setiap konstruk/variabel adalah $>0,5$. Berdasarkan pada hasil tersebut dapat disimpulkan bahwa convergent validity instrumen yang digunakan pada penelitian ini memenuhi syarat. Nilai cross loading pada tabel 1 menunjukan nilai lebih dari $>0,6$ untuk setiap variabel. Berdasarkan pada hasil tersebut dapat disimpulkan bahwa discriminant validity instrumen pada penelitian ini memenuhi syarat.

Tabel 2 menunjukan pengujian reliabilitas instrumen. Reliabilitas dilihat dari nilai croanbach's alpha dan composite reliability pada setiap konstruk/variabel. Reliabilitas instrumen dikatakan memenuhi syarat apabila nilai croanbach's alpha dan nilai composite reliability adalah $>0,7$ untuk confirmatory research dan > 0,6 untuk exploratory research (Ghozali \& Latan, 2014; Wijaya, 2019). Berdasarkan pada tabel 2 nilai Croanbach's Alpha instrumen penelitian ini adalah $>$ 0,6 dan nilai Composite Reliability instrument penelitian ini adalah $>0,6$, sehingga dapat simpulkan reliabilitas instrumen dalam penelitian ini memenuhi syarat.

\section{Hasil Pengujian Hipotesis}

Hasil pengujian hipotesis 1-15 dipaparkan dalam tabel 3. Hasil pengujian hipotesis pada tabel 3 menunjukan bahwa terdapat 3 variabel eksternal yang tidak berpengaruh signifikan terhadap variabel
Tabel 3. Hasil Pengujian Hipotesis 1 sampai dengan Hipotesis 14

\begin{tabular}{|c|c|c|c|c|}
\hline \multicolumn{2}{|r|}{ Hipotesis } & $\begin{array}{c}\text { Path } \\
\text { Coefficient }\end{array}$ & $\begin{array}{c}P- \\
\text { Values }\end{array}$ & Kesimpulan \\
\hline $\mathrm{H} 1$ & $\mathrm{EXP} \rightarrow \mathrm{PU}$ & 0,151 & 0,073 & $\begin{array}{c}\text { Tidak } \\
\text { Terdukung }\end{array}$ \\
\hline $\mathrm{H} 2$ & $\mathrm{EXP} \rightarrow \mathrm{PEOU}$ & 0,186 & 0,052 & $\begin{array}{c}\text { Tidak } \\
\text { Terdukung }\end{array}$ \\
\hline $\mathrm{H} 3$ & $\mathrm{SN} \rightarrow \mathrm{PEOU}$ & 0,149 & 0,240 & $\begin{array}{c}\text { Tidak } \\
\text { Terdukung }\end{array}$ \\
\hline $\mathrm{H} 4$ & $\mathrm{SN} \rightarrow \mathrm{PU}$ & $-0,021$ & 0,855 & $\begin{array}{c}\text { Tidak } \\
\text { Terdukung }\end{array}$ \\
\hline H5 & $\begin{array}{l}\text { ENJOY } \rightarrow \\
\text { PEOU }\end{array}$ & 0,470 & 0,000 & Terdukung \\
\hline $\mathrm{H} 6$ & ENJOY $\rightarrow$ PU & 0,136 & 0,182 & $\begin{array}{c}\text { Tidak } \\
\text { Terdukung }\end{array}$ \\
\hline $\mathrm{H} 7$ & $\mathrm{CA} \rightarrow \mathrm{PEOU}$ & $-0,020$ & 0,809 & $\begin{array}{c}\text { Tidak } \\
\text { Terdukung }\end{array}$ \\
\hline $\mathrm{H} 8$ & $\mathrm{CA} \rightarrow \mathrm{PU}$ & $-0,076$ & 0,296 & $\begin{array}{c}\text { Tidak } \\
\text { Terdukung }\end{array}$ \\
\hline $\mathrm{H} 9$ & $\mathrm{SE} \rightarrow \mathrm{PEOU}$ & 0,223 & 0,013 & Terdukung \\
\hline $\mathrm{H} 10$ & $\mathrm{SE} \rightarrow \mathrm{PU}$ & 0,195 & 0,006 & Terdukung \\
\hline $\mathrm{H} 11$ & PEOU $\rightarrow$ PU & 0,452 & 0,000 & Terdukung \\
\hline $\mathrm{H} 12$ & PEOU $\rightarrow$ AT & 0,280 & 0,012 & Terdukung \\
\hline $\mathrm{H} 13$ & $\mathrm{PU} \rightarrow \mathrm{AT}$ & 0,637 & 0,000 & Terdukung \\
\hline $\mathrm{H} 14$ & $\mathrm{AT} \rightarrow \mathrm{I}$ & 0,585 & 0,000 & Terdukung \\
\hline $\mathrm{H} 15$ & $I \rightarrow U$ & 0,581 & 0,000 & Terdukung \\
\hline & rsepsi & udahan & dan & persepsi \\
\hline
\end{tabular}

Acceptance Model (TAM).

Variabel eksternal tersebut adalah variabel pengalaman mahasiswa dalam menggunakan komputer, norma subyektif, dan kecemasan dalam menggunakan komputer. Variabel kenyamanan dalam menggunakan e-learning Exelsa Moodle berpengaruh signifikan terhadap persepsi kemudahan tetapi tidak berpengaruh signifikan terhadap persepsi kebermanfaatan. Seluruh variabel Technology Acceptance Model memiliki pengaruh signifikan.

\section{PEMBAHASAN}

Pengalaman dalam menggunakan Komputer dan teknologi informasi tidak berpengaruh terhadap persepsi kemudahan dan persepsi kebermanfaatan. Hal ini disebabkan karena mahasiswa saat ini termasuk ke dalam Generasi Y (kelahiran 1990-sekarang) yang termasuk ke dalam digital natives. Mahasiswa ini terlahir dan tumbuh dengan komputer dan teknologi 
informasi. Hal ini mengakibatkan pengalaman tidak diperlukan lagi, karena teknologi informasi sudah menjadi bagian dari hidup mereka. Norma subjektif tidak berpengaruh terhadap persepsi kemudahan dan persepsi kebermanfaatan. Hal ini disebabkan karena mahasiswa tidak memerlukan pengaruh dari orang lain dan lingkungan di sekitarnya untuk mempersepsikan bahwa e-learning Exelsa Moodle mudah dan bermanfaat. Hal ini juga berkaitan dengan latar belakang mahasiswa yang merupakan digital natives.

Kenyamanan dalam menggunakan $e$ learning Exelsa Moodle berpengaruh terhadap persepsi kemudahan. Hasil ini sesuai dengan hipotesis yang diajukan. Meskipun demikian, kenyamanan dalam menggunakan e-learning Exelsa Moodle tidak berpengaruh terhadap persepsi kebermanfaatan mahasiswa terhadap $e$ learning Exelsa Moodle. Hal ini disebabkan karena ketika mahasiswa mempersepsikan bahwa e-learning Exelsa Moodle nyaman untuk digunakan, mereka hanya mempersepsikan bahwa penggunaan $e$ learning tersebut mudah untuk digunakan, tetapi tidak mempersepsikan bahwa $e$ learning tersebut bermanfaat bagi proses pembelajaran. Hal ini menjadi penting bagi dosen untuk menekankan kepada para mahasiswa bahwa penggunaan e-learning Exelsa Moodle bertujuan untuk membantu proses pembelajaran agar menjadi lebih baik.

Kecemasan dalam menggunakan Komputer dan Teknologi Informasi tidak mempengaruhi persepsi kemudahan dan persepsi kebermanfaatan. Hal ini disebabkan karena mahasiswa tidak khawatir terhadap penggunaan komputer dan teknologi informasi. Mahasiswa sudah terbiasa dengan komputer dan teknologi informasi. Hal ini disebabkan karena mereka adalah digital natives yang lahir dan tumbuh dengan komputer dan teknologi informasi.

Variabel berikutnya adalah Self Efficacy. Hasil dari tabel 4 menunjukan bahwa variabel Self Efficacy mempengaruhi persepsi kemudahan dan persepsi kebermanfaatan. Hasill ini sesuai dengan hipotesis yang diajukan. Seluruh variabel TAM (Technology Acceptance Model) yaitu : Perceived Ease of Use (Persepsi Kebermanfaatan Penggunaan e-learning Exelsa Moodle), Perceived Usefulness (Persepsi Kemudahan Penggunaan elearning Exelsa Moodle), Attitude Towards Usage (Sikap dalam Menggunakan elearning Exelsa Moodle), Intention to Use (Niat untuk menggunakan e-learning Exelsa Moodle), dan Actual Use, semua berpengaruh (signifikan). Hasil ini sesuai dengan hipotesis yang diajukan. Hal ini menunjukan bahwa, secara umum elearning Exelsa Moodle dapat diterima oleh mahasiswa Program Studi Pendidikan Akuntansi Universitas Sanata Dharma.

Penelitian ini menunjukan bahwa latar belakang mahasiswa yang merupakan digital natives tidak berpengaruh terhadap bagaimana mahasiswa akan menilai $e$ learning tersebut mudah digunakan atau tidak dan bermanfaat untuk digunakan atau tidak. Sebagai digital natives teknologi informasi sudah menjadi bagian dari kehidupan mahasiswa, sehingga mahasiswa tidak akan menganggap hal tersebut sebagai hal yang sulit dan tidak akan mempertanyakan kebermanfaatan dari penggunaan e-learning tersebut. Faktor pengalaman dalam menggunakan teknologi informasi, norma subyektif, dan kecemasan, tidak mempengaruhi persepsi mahasiswa terhadap e-learning Exelsa Moodle. Lebih lanjut, faktor kenyamanan berpengaruh signifikan terhadap persepsi kemudahan dan self efficacy berpengaruh terhadap persepsi kemudahan dan persepsi kebermanfaatan menggunakan e-learning. Hal ini menunjukan bahwa mahasiswa merasa percaya diri dan nyaman ketika menggunakan Exelsa Moodle. 


\section{SIMPULAN}

Hasil dalam penelitian ini menunjukkan bahwa tidak semua variabel eksternal yang diajukan dalam GETAMEL berpengaruh signifikan terhadap penerimaan e-learning Exelsa Moodle di Program Studi Pendidikan Akuntansi Universitas Sanata Dharma. Hal ini disebabkan karena latar belakang mahasiswa yang merupakan digital natives (generasi y). Oleh sebab itu, penelitian selanjutnya perlu untuk mengeksplorasi faktor-faktor lain yang lebih sesuai dengan penerimaan terhadap e-learning, khususnya untuk mahasiswa dengan latar belakang digital natives. Meskipun demikian, penelitian ini tidak bisa digeneralisasi secara umum. Hasil ini dalam penelitian ini hanya bisa disimpulkan untuk mahasiswa Program Studi Pendidikan Akuntansi Universitas Sanata Dharma. Oleh sebab itu, penelitian selanjutnya dapat memperluas cakupan responden sehingga kesimpulan dapat digeneralisasi secara umum.

Semua Variabel TAM berpengaruh signifikan. Hal ini berarti bahwa e-learning Exelsa Moodle dapat diterima oleh mahasiswa Program Studi Pendidikan Akuntansi Universitas Sanata Dharma. Hasil ini juga memperkuat penelitian-penelitian terdahulu khususnya mengenai TAM dan $e$ learning.

\section{REFERENSI}

Abbad, M. M., Morris, D., \& de Nahlik, C. (2009). Looking under the Bonnet: Factors affecting student adoption of E-learning systems in Jordan. International Review of Research in Open and Distance Learning, 10(2), 1-25.

Abdullah, F., Ward, R., \& Ahmed, E. (2017). Investigating the influence of the most commonly used external variables of TAM on students' Perceived Ease of Use (PEOU) and Perceived Usefulness (PU) of e-portfolios. Computers in Human Behavior, 63, 75-90. https://doi.org/10.1016/j.chb.2016.05.014

Agudo-Peregrina, Á. F., Hernández-García, Á., \& Pascual-Miguel, F. J. (2014). Behavioral intention, use behavior and the acceptance of electronic learning systems: Differences between higher education and lifelong learning. Computers in Human Behavior, 34,
301-314.

https://doi.org/10.1016/j.chb.2013.10.035

Bandura, A. (1977). Bandura (1977). Pyschological Review, 84(2), 191-215. https://doi.org/10.1037/0033-295X.84.2.191

Brown, I., \& Inouye, D. K. (1978). Learned helplessness through modeling: The role of perceived similarity in competence. Journal of Personality and Social Psychology, 36(8), 900-908. https://doi.org/10.1037/00223514.36.8.900

Chen, H. R., \& Tseng, H. F. (2012). Factors that influence acceptance of web-based elearning systems for the in-service education of junior high school teachers in Taiwan. Evaluation and Program Planning, 35(3), 398-406.

https://doi.org/10.1016/j.evalprogplan.2011 .11 .007

Cheng, Y. (2011). Antecedents and consequences of e-learning acceptance. Information Systems Journal, 21(3), 269-299. https://doi.org/https://doi.org/10.1111/j.13 65-2575.2010.00356.x

Cheng, Y. M. (2011). Antecedents and consequences of e-learning acceptance. Information Systems Journal, 21(3), 269-299. https://doi.org/10.1111/j.13652575.2010.00356.x

Cohen, J. (1992). A power primer. Psychological Bulletin, 112(1), 155-159.

Davis. (1989). Perceived Usefulness, Perceived Ease of Use, and User Acceptance of. Management Information Systems Research Center, 13(3), 319-340.

Davis, F. (1985). A Technology Acceptance Model for Empirical Testing New End User Information Systems: Theory and Results. https://doi.org/oclc/56932490

Engelbrecht, E. (2005). Adapting to changing expectations: Post-graduate students' experience of an e-learning tax program. Computers and Education, 45(2), 217-229. https://doi.org/10.1016/j.compedu.2004.08. 001

Fazil, A., \& Rupert, W. (2016). Developing a General Extended Technology Acceptance Model for E-Learning (GETAMEL) by analysing commonly used external factors. Computers in Human Behavior, 56, 238-256. https://doi.org/10.1016/j.chb.2015.11.036

Fishbein, M., \& Ajzen, I. (1975). Belief, attitude, intention, and behavior: An introduction to theory and research. Addison-Wessley.

Ghozali, I., \& Latan, H. (2014). Partial Least Squares 
Konsep, Teknik, dan Aplikasi Menggunakan Program Smart PLS 3.0 Untuk Penelitian Empiris. Badan Penerbit Universitas Diponegoro.

Igbaria, M., \& Parasuraman, S. (1989). A Path Analytic Study of Individual Characteristics, Computer Anxiety and Attitudes toward Microcomputers. Journal of Management, 15(3), 373-388. https://doi.org/10.1177/0149206389015003 02

Kerka, S. (1999). Distance Learning, the Internet, and the World Wide Web. Eric Digest, 1-7.

King, W. R., \& He, J. (2006). A meta-analysis of the technology acceptance model. Information and Management, 43(6), 740-755. https://doi.org/10.1016/j.im.2006.05.003

Lee, Y. H., Hsieh, Y. C., \& Chen, Y. H. (2013). An investigation of employees' use of e-learning systems: Applying the technology acceptance model. Behaviour and Information Technology, 32(2), 173-189. https://doi.org/10.1080/0144929X.2011.577 190

Lee, Y. H., Hsieh, Y. C., \& Ma, C. Y. (2011). A model of organizational employees' e-learning systems acceptance. Knowledge-Based Systems, 24(3), 355-366. https://doi.org/10.1016/j.knosys.2010.09.00 5

Mohammadi, H. (2015). Investigating users' perspectives on e-learning: An integration of TAM and IS success model. Computers in Human Behavior, 45, 359-374. https://doi.org/10.1016/j.chb.2014.07.044

Park, S. Y. (2009). An Analysis of the Technology Acceptance Model in Understanding University Students' Behavioral Intention to Use e-Learning. Journal of Educational Technology \& Society, 12(3), 150-162.

Park, Y., Son, H., \& Kim, C. (2012). Investigating the determinants of construction professionals' acceptance of web-based training: An extension of the technology acceptance model. Automation in Construction, 22, 377386.

https://doi.org/10.1016/j.autcon.2011.09.01 6

Purnomo, S. H., \& Lee, Y.-H. (2012). E-learning adoption in the banking workplace in
Indonesia. Information Development, 29(2), 138-153. https://doi.org/10.1177/0266666912448258

Sholihin, M., \& Ratmono, D. (2013). Analisis SEMPLS dengan Warp PLS 3.0 (1st ed.). Andi.

Shroff, R. H., Deneen, C. C., \& Ng, E. M. W. (2011). Analysis of the technology acceptance model in examining students' behavioural intention to use an e-portfolio system. Australasian Journal of Educational Technology, 27(4), 600-618. https://doi.org/10.14742/ajet.940

Šumak, B., Heričko, M., \& Pušnik, M. (2011). A meta-analysis of e-learning technology acceptance: The role of user types and elearning technology types. Computers in Human Behavior, 27(6), 2067-2077. https://doi.org/10.1016/j.chb.2011.08.005

Venkatesh, V., \& Bala, H. (2008). Technology acceptance model 3 and a research agenda on interventions. Decision Sciences, 39(2), 273-315. https://doi.org/10.1111/j.15405915.2008.00192.x

Venkatesh, V., \& Davis, F. D. (2000). A Theoretical Extension of the Technology Acceptance Model: Four Longitudinal Field Studies. Management Science, 46(2), 186-204. https://doi.org/http://dx.doi.org/10.1016/j.p roci.2004.08.141

Welsh, E. T., Wanberg, C. R., Brown, K. G., \& Simmering, M. J. (2003). E-learning: emerging uses, empirical results and future directions. International Journal of Training and Development, 7(4), 245-258. https://doi.org/10.1046/j.13603736.2003.00184.x

Wijaya, A. (2019). Metode Penelitian Menggunakan Smart PLS 03 (1st ed.). Innosain.

Wood, R., \& Bandura, A. (1989). Social cognitive theory of organizational management. Academy of Management Review, 14(3), 361-384. https://doi.org/10.5465/AMR.1989.4279067

Yoo, S. J., Han, S. H., \& Huang, W. (2012). The roles of intrinsic motivators and extrinsic motivators in promoting e-learning in the workplace: A case from South Korea. Computers in Human Behavior, 28(3), 942950.

https://doi.org/10.1016/j.chb.2011.12.015 